УДК 340.132 .2

DOI https://doi.org/10.32849/2663-5313/2020.1.26

Людмила Андрусів, канд. юрид. наук, дочент, професор кафедри сочіально-гуманітарних дисциплін Прикарпатського факультету Національної академії внутрішніх справ

\title{
ОПРИЛЮДНЕННЯ НОРМАТИВНО-ПРАВОВИХ АКТІВ: ДОСВІД ВЕЛИКОГО ГЕРЦОГСТВА ЛЮКСЕМБУРГ ТА КОРОЛІВСТВА БЕЛЬГІЇ
}

У статті проведено аналіз правової регламентацї оприлюднення нормативно-правових актів у Великому Гериогстві Люксембург та Королівстві Бельгї. Встановлено, що техніка оприлюднення нормативно-правових актів у Великому Герцогстві Люксембург й Королівстві Бельгія базується на історичних монархічних традиціях та зумовлена формою правління держави. Констатовано, що оприлюднення нормативно-правових актів у Великому Гериогстві Люксембург має певні особливості, які пов'язані з наявністю спеиіальних нормативно-правових актів, шо регулюють порядок оприлюднення. Зокрема, порядок оприлюднення нормативно-правових актів у Великому Гериогстві Люксембург регулюється Указом Великого Гериога «Регулювання публікаиії законів» від 22 жовтня 1842 року та Указом Великого Гериога «Цодо публікаиї Меморіалу у двох частинах» від 21 вересня 1859 року. Також у статті досліджено порядок та форми офіиійного оприлюднення нормативноправових актів у Великому Гериогстві Люксембург та Королівстві Бельгія. Установлено, шо закони оприлюднює Великий Гериог протягом трьох місяиів після прийняття Палатою депутатів у формі офіиійного опублікування у друкованому виданні «Ме́тогіal». Друковане видання «Mе́тогіаl» у повному обсязі доступне і в електронному варіанті на сайті «legilux.lu» та иілком безкоштовно. У Королівстві Бельгія оприлюднення законів відбувається шляхом королівського санкиіонування закону та проставлянням підпису на ньому, шо є символічним «дозволом» короля на існування закону, а його оприлюднення відбувається одночасно із санкиією. Разом із тим контрасигначія також робиться королем, оскільки король Бельгї очолює федеральну виконавчу владу, то його підпис на федеральному нормативно-правовому акті означає не тільки його санкиіонування та оприлюднення, а ще й те, що він підлягає виконанню. У статті встановлено, що у Королівстві Бельгія використовується така форма оприлюднення законів, як публікаиія в офіиійному друкованому виданні «Mопiteurbelge». Oфiиійне оприлюднення нормативно-правових актів у Королівстві Бельгія здійснюється двома мовами: французькою та голландською.

Ключові слова: нормативно-правовий акт, конституція, закон, оприлюднення нормативноправових актів, опублікування нормативно-правових актів, друковане видання, дата офіційного опублікування.

Постановка проблеми. Формування правової регламентації та техніко-правової моделі оприлюднення нормативно-правових актів в Україні потребує дослідження зарубіжного досвіду у вказаній сфері. Аналіз практики правового забезпечення та техніки оприлюднення нормативно-правових актів дає можливість встановити особливості оприлюднення у певних країнах. Водночас констатуємо те, що в Україні відсутні наукові дослідження оприлюднення нормативно-правових актів зарубіжних країн. 3 огляду на потребу формування техніки оприлюднення нормативно-правових актів, використання європейського досвіду, в статті для дослідження вибрано порядок оприлюднення нормативно-правових актів у Великому Герцогстві Люксембург й Королівстві Бельгія.

Метою статті $\epsilon$ встановлення особливостей та правової регламентації оприлюднення нормативно-правових актів у Великому Герцогстві Люксембург й Королівстві Бельгія.

Виклад основного матеріалу. Порядок оприлюднення нормативно-правових актів у Великому Герцогстві Люксембург визначається Конституцією, Указом Великого Герцога «Регулювання публікації законів» від 22 жовтня 1842 року та Указом Великого Герцога «Щодо публікації Меморіалу у двох частинах» від 21 вересня 1859 року. Зокрема, стаття 112 Конституції визначає: «Закон, 
указ, декрет муніципальної адміністрації $є$ обов'язковими лише після оприлюднення у формі, визначеній законом» [1]. Зазначимо, що відповідно до статті 34 Конституції Великий Герцог оприлюднює закони протягом трьох місяців після прийняття Палатою депутатів (парламентом) [1]. Це положення означає, що нормативно-правовий акт повинен бути опублікований у друкованому виданні «Mémorial» не пізніше ніж через три місяці після прийняття Палатою депутатів (парламентом).

Закони та інші нормативно-правові акти набирають чинності в усьому Великому Герцогстві Люксембург через чотири дні після публікації в «Mémorial», тобто дано чотири повні дні, включаючи день дати публікації, якщо тільки у самому нормативно-правовому акті не встановлено коротший або довший період.

Відповідно до статті 3 Указу Великого Герцога «Регулювання публікації законів», датою опублікування нормативно-правового акта у «Mémorial» є дата публікації, яка вказується у верхній частині титульного аркуша Mémorial, що є днем офіційного розповсюдження. Вважаємо таке положення ключовим і таким, що відповідає принципу правової визначеності, оскільки виключає можливість сумнівів і неоднозначностей у визначенні дати виходу офіційного журналу «Mémorial».

Слід зазначити, що, відповідно до статті 4 Указу Великого Герцога «Регулювання публікації законів» від 22 жовтня 1842 року, регламенти та інші підзаконні нормативно-правові акти, які визначають правила поведінки певної муніципальної ради, набувають чинності після процедури оприлюднення та розміщення у відповідних муніципалітетах. Окрім того, такі нормативно-правові акти надсилаються Вищому суду юстиції та місцевим судам. Мер (bourgmestre) надсилає сертифікат такого акта до губернатора (Gouverneur), після чого буде надано дозвіл на його опублікування y «Mémorial». Такі нормативно-правові акти набувають чинності наступного дня після дня їх публікації. Також підлягають опублікуванню в «Mémorial» рішення Конституційного Суду протягом тридцяти днів 3 дня їх оголошення й постанови Адміністративного суду, які скасовують нормативно-правовий акт або адміністративний акт нормативного характеру [2].

Важливою є вимога, що після прийняття закону Палатою депутатів текст закону більше не може бути змінений, окрім помилок текстового матеріалу (орфографічні помилки і т. д.). Текст опублікованого нор- мативно-правового акта у збірнику законодавства «Mémorial» має бути суворо ідентичним тому, який був прийнятий Палатою депутатів і оприлюднений Великим Герцогом. У разі якщо є суттєві помилки в тексті нормативно-правового акта, вони вимагають подальшого законодавчого врегулювання Аналогічною є вимога, що нормативно-правові акти Великого Герцога або міністерств, які опубліковані у «Mémorial», повинні правильно відтворювати текст нормативно-правового акта, поданого для підпису Великому Герцогу.

Тексти законів, указів, постанов та розпоряджень, що направлені на оприлюднення, повинні охоплювати такі елементи, як: назва 3 датою прийняття; автор (ініціатор) нормативно-правового акта та його повні дані; преамбула; вступне речення до нормативних положень статей; нормативні положення статей; порядок оприлюднення (тільки у випадку оприлюднення закону); місце, дата прийняття та підпис Великого Герцога (якщо нормативно-правовий акт закон чи указ Великого Герцога) або підпис уповноваженого члена Уряду (якщо нормативно-правовий акт уряду чи міністерства); міністерський контрпідпис, якщо нормативно-правовий акт - закон або указ Великого Герцога (контрасигнація); номер парламентського документа та парламентських засідань; будь-які додатки [2].

Якщо під час публікації у «Mémorial» допущено суто технічні помилки в тексті закону, нормативно-правових актах Великого Герцога або міністерств, то вони виправляються у наступному номері «Mémorial» iз позначенням «Виправлення». Слід зазначити, що використовувати цей спосіб усунення помилок у тексті публікації «виправлення» до законів або до герцогських чи міністерських нормативно-правових актів - можна лише у рідкісних випадках і слід застосовувати з великою обережністю у тих випадках, коли істотна помилка очевидна (орфографічна тощо).

Офіційний журнал Великого Герцогства Люксембург «Mémorial» складається з трьох окремих частин, кожна 3 яких має власне видання: Збірник законів, який має назву «Mémorial A» (le Recueil de Législation, dit Mémorial A), Адміністративно-господарський збірник, що має назву «Mémorial B» (le Recueil Administratif et Économique, dit Mémorial B) і Збірник товариств та асоціацій - «Mémorial C» (le Recueil Administratif et Économique, dit Mémorial B, et le Recueil des Sociétés et Associations, dit Mémorial C).

Згідно з вимогами статті 3 Указу Великого Герцога «Щодо публікації Меморіалу 
у двох частинах» від 21 вересня 1859 року «передплата на обидві частини «Mémorial» (A та В) є обов'язковою для муніципалітетів». У збірнику законів «Mémorial A» публікуються законодавчі акти відповідно до процедур, встановлених законодавством.

Адміністративно-господарський збірник «Mémorial B» охоплює:

1) нормативно-правові акти, публікація яких в «Mémorial B» прямо встановлена у законодавчих актах;

2) нормативно-правові акти, публікація яких в «Mémorial В» відбувається на підстав рішення голови уряду [3].

$\mathrm{У}_{\text {ci }}$ частини збірника законодавства «Mémorial» повністю доступні на сайті «legilux.lu» цілком безкоштовно. Компанія, відповідальна за друк збірника законодавства, зберігає усі примірники «Mémorial», а також минулі випуски можна знайти в Національній бібліотеці, Національному apхіві або на сайті «legilux.lu». Також на цьому сайті можна знайти зміст«Mémorial» (A, В та С) поточного року [4].

Офіційний журнал Великого Герцогства Люксембург «Mémorial» з 1839 року і до сьогодні функціонує в режимі онлайн на сайті «legilux». Також передбачена можливість громадянам отримати щорічний DVDROM, що містить усі збірники (A, B і C). Щороку, починаючи з 1996 року, щорічний зміст «Mémorial»(A, В та С) видається на комп'ютерному носії, зміст якого є ідентичний оригінальному випуску на папері. До 2001 року це були компакт-диски, а потім, починаючи з 2002 року («Mémorial» 2001), - DVD-ROM. Можемо підсумувати, що будь-яка особа мала можливість починаючи з 1996 року доступу до всіх текстів нормативно-правових актів, опублікованих $\mathrm{y} \ll$ Mémorial».

Порядок оприлюднення нормативноправових актів Королівства Бельгія визначається Конституцією Бельгії та Законом «Про використання мов у законодавчих питаннях оприлюднення, публікації та введення в дію нормативно-правових актів» від 31 травня 1961 року.

На федеральному рівні оприлюднення нормативно-правових актів регулюється статтею 109 Конституції, а саме: «король промульгує і оприлюднює закони». Відповідно до цієї статті, король має владу санкціонувати й оприлюднювати закони, тоді як у суб̆'єктах федерації це завдання покладено на федеративні уряди. Таке королівське санкціонування закону та проставляння підпису на ньому є символічним погодженням, «дозволом» на існування закону. Також санкціонування королем закону може використо- вуватися і як політична дія. Оприлюднення відбувається одночасно із санкцією [5].

Оскільки Король Бельгії очолює федеральну виконавчу владу, то його підпис на федеральному нормативно-правовому акті означає не тільки його санкціонування та оприлюднення, а ще й те, що він підлягає виконанню.

Відповідно до статті 4 Закону «Про використання мов у законодавчих питаннях оприлюднення, публікації та введення в дію нормативно-правових актів», закони після їх промульгації публікуються в офіційному друкованому виданні «Moniteur belge» французькою та голландською мовами. Тексти законів французькою й голландською мовами повинні строго відповідати один одному. Закони набувають юридичної сили на десятий день після їх опублікування, якщо інше не встановлено самим законом [6].

Відповідно до статті 6 вказаного закону, королівські укази та нормативно-правові акти уряду й міністерств також публікуються в офіційному друкованому виданні «Moniteur belge» французькою та голландською мовами й набувають юридичної сили на десятий день після їх опублікування, якщо інше не встановлено самими нормативно-правовими актами. Міжнародні договори та угоди, стороною яких є Королівство Бельгія, публікуються в офіційному виданні «Moniteur belge» мовою оригіналу із перекладами французькою та голландською мовами, якщо оригінальний текст не був офіційно складений французькою чи голландською мовами (стаття 8) [7].

$\mathrm{y}$ разі наявності розбіжностей в текстах нормативно-правових актів французькою та голландською мовами використовуються правила статті 7 Закону, зокрема, така невідповідність вирішується суб'єктом правотворчості через використання правил тлумачення правових норм. Таке тлумачення повинно здійснюватися без шкоди, зміни тексту нормативно-правового акта іншою мовою.

Варте уваги закріплення у законі (стаття 3) самої форми (формуляру) оприлюднення нормативно-правових актів залежно від їх виду. Зокрема, промульгація (санкціонування королем), оприлюднення рішень і законів, які приймаються відповідно до статей 74, 77, 78 Конституції, здійснюється у такому формулярі:

ФІЛІП, Король бельгійців (FILIP, Koning der Belgen),

для усіх, у цей час та на майбутнє, Вітає.

Палата представників прийняла і ми санкціонуємо таке:

(текст Закону)

Оприлюднити цей закон та наказуємо скріпити закон державною печаткою й опублікувати в «Moniteur belge» 
Підпис короля (FILIP, Koning der Belgen)

Мокра печатка

Укази Фламандського парламенту, парламенту Французької громади і парламенту Валлонії оприлюднюються урядами відповідних парламентів згідно зі статтею 54 Закону «Про спеціальні інституційні реформи» від 8 серпня 1980 року [3].

Відповідно до § 1 цього закону оприлюднення та опублікування нормативно-правових актів (указів, декретів) парламенту Фламандського співтовариства відбувається у такому формулярі:

Парламент Фламандського співтовариства ухвалив,

та Уряд санкціонує таке:

(текст)

Оприлюднити цей указ, скріпити печаткою й опублікувати в «Moniteur belge»

Підпис уповноваженої особи Уряду

Мокра печатка

Відповідно до § 2 вказаного закону оприлюднення та опублікування нормативноправових актів (указів, декретів) парламенту Французького співтовариства відбувається так:

Парламент Французького співтовариства ухвалив,

та Уряд санкціонує таке:

(текст)

Оприлюднити цей указ, скріпити печаткою й опублікувати в «Moniteur belge»

Підпис уповноваженої особи Уряду

мокра печатка

Відповідно до § 3 цього закону оприлюднення та опублікування нормативно-правових актів (указів, декретів) парламенту Валлонського співтовариства відбувається так:

Парламент Валлонського співтовариства ухвалив,

та Уряд санкціонує таке:

(текст)

Оприлюднити цей указ, скріпити печаткою й опублікувати в «Moniteur belge»

Підпис уповноваженої особи Уряду

мокра печатка

\section{Висновки}

Техніка оприлюднення нормативно-правових актів у Великому Герцогстві Люксембург і Королівстві Бельгія базується на історичних монархічних традиціях та зумовлена формою правління держави. Дослідження й аналіз законодавства дають можливість визначити, що оприлюднення нормативноправових актів у Великому Герцогстві Люксембург має такі особливості:

- наявність спеціальних нормативноправових актів, що регулюють порядок оприлюднення, зокрема Указу Великого
Герцога «Регулювання публікації законів» від 22 жовтня 1842 року та Указу Великого Герцога «Щодо публікації Меморіалу у двох частинах» від 21 вересня 1859 року;

- закони оприлюднює Великий Герцог протягом трьох місяців після прийняття Палатою депутатів шляхом офіційного опублікування у друкованому виданні «Mémorial»;

- в Указі Великого Герцога «Регулювання публікації законів» від 22 жовтня 1842 року містяться вимоги щодо нормативно-правових актів, які надсилаються на офіційне опублікування та гарантії забезпечення ідентичності оприлюднених нормативно-правових актів оригіналам;

- друковане видання «Mémorial» складається 3 трьох окремих частин, кожна 3 яких має власне видання: Збірник законів, який має назву «Mémorial A» (le Recueil de Législation, dit Mémorial A), Адміністративногосподарський збірник під назвою «Mémorial B» (le Recueil Administratif et Économique, dit Mémorial B) і Збірник товариств та асоціацій «Mémorial C» (le Recueil Administratif et Économique, dit Mémorial B, et le Recueil des Sociétés et Associations, dit Mémorial C);

- усі частини збірника законодавства «Mémorial» видаються у паперовій формі та повністю доступні на сайті «legilux.lu» цілком безкоштовно.

Оприлюднення нормативно-правових актів у Королівстві Бельгія має такі особливості:

- наявність спеціального нормативноправового акта, який регулює оприлюднення, а саме Закону «Про використання мов у законодавчих питаннях оприлюднення, публікації та введення в дію нормативноправових актів» від 31 травня 1961 року;

- оприлюднюе закони, відповідно до статті 109 Конституції Бельгії, король, який має владу санкціонувати й оприлюднювати закони, а в суб'єктах федерації це завдання покладено на федеративні уряди;

- оприлюднення законів відбувається шляхом королівського санкціонування закону та проставлянням підпису на ньому, що $є$ символічним «дозволом» короля на існування закону, а його оприлюднення відбувається одночасно із санкцією;

- контрасигнація також робиться королем, оскільки король Бельгії очолює федеральну виконавчу владу, то його підпис на федеральному нормативно-правовому акті означає не тільки його санкціонування та оприлюднення, а ще й те, що він підлягає виконанню;

- формою оприлюднення законів є їх публікація в офіційному друкованому 
виданні «Moniteurbelge» французькою та голландською мовами;

- також у Законі «Про використання мов у законодавчих питаннях оприлюднення, публікації та введення в дію нормативноправових актів» від 31 травня 1961 року чітко визначено форму оприлюднення нормативно-правових актів і гарантії їх відповідності оригіналам.

\section{Список використаних джерел:}

1. Constitution du grand-duché de Luxembourg. URL : http://data.legilux.public.lu/file/eli-etat-legrecueil-constitution-20161020-fr-pdf.pdf (дата звернення: 16.11.2019).

2. Arrêté royal grand-ducal du 22 octobre $1842, \mathrm{~N}^{\circ} 1943 \mathrm{c} / 1297$, réglant le mode de publication des lois. URL : http://legilux.public.lu/eli/etat/ leg/argd/1842/10/22/n1/jo (дата звернення: 16.11.2019)

3. Arrêté royal grand-ducal du 21 septembre 1859 concernant la publication du Mémorial en deux parties. URL : http://legilux.public.lu/eli/ etat/leg/argd/1859/09/21/n1/jo (дата звернення: 16.11.2019)

4. La procedure legislative et reglementaire. 2015. Ministère d'État - Service Central de Législation Grand-Duché de Luxembourg. URL : http://data. legilux.public.lu/file/eli-etat-leg-recueil-procedure legislative-20150301-fr-pdf.pdf (дата звернення: 16.11.2019)

5. La Constitution Belge. URL : https://www. dekamer.be/kvver/pdf sections/publications/ constitution/GrondwetF̄̄.pdf (дата звернення: 16.11.2019)

6. Loi relative à l'emploi des langues en matière législative, à la présentation, à la publication et à l'entrée en vigueur des textes légaux et réglementaires. 31 mai 1961. URL : http://www.ejustice.just.fgov. $\mathrm{be} / \mathrm{cgi}$ loi/change lg.pl?language $=\mathrm{fr} \& l \mathrm{a}=\mathrm{F} \& \mathrm{cn}$ $=1961053130 \&$ table_name $=$ loi (дата звернення: 16.11.2019)

7. Loi spéciale de réformes institutionnelles 8 aout 1980. URL: https://wallex.wallonie.be/index. php?doc=3144 (дата звернення: 16.11.2019).

The article analyzes the legal regulation of the promulgation of legal acts in the Grand Duchy of Luxembourg and the Kingdom of Belgium. It is established that the technique of promulgation of legal acts in the Grand Duchy of Luxembourg and the Kingdom of Belgium is based on historical monarchical traditions and predetermined by the form of the government. It is noted that the promulgation of legal acts in the Grand Duchy of Luxembourg is characterized by certain features that are linked with the existence of specific legal acts governing the procedure for publication. In particular, the procedure for the promulgation of legal acts in the Grand Duchy of Luxembourg is governed by the Grand Duke's Decree on the Regulation of Publication of Lawes of 22 October 1842 and the Grand Duke's Decree on the Publication of the Memorial in Two Parts of 21 September 1859. The article also examines the procedure and method of officially promulgating legal acts in the Grand Duchy of Luxembourg and the Kingdom of Belgium. It is established that the lawes are promulgated by the Grand Duke within three months after the adoption of the House of Deputies by an official publication in the «Mémorial». The official print edition of Mémorial is also available electronically at legilux.lu and is free of charge. In the Kingdom of Belgium, the promulgation of lawes is done by the royal authorization of the law and the signature on it, which is a symbolic «permission» of the king for the existence of the law, and its publication occurs simultaneously with the sanction. However, the counter-signal is also made by the king, since the king of Belgium is the head of the federal executive power, his signature on a federal legal act means not only its authorization and promulgation, but also that it is in force. The article found that the Kingdom of Belgium uses such method of promulgation as the publication in the official issue of «Moniteurbelge». The official publication of legal acts in the Kingdom of Belgium is in two languages: French and Dutch.

Key words: legal act, constitution, law, promulgation of legal acts, publication of legal acts, printed edition, date of the official publication. 